\title{
Molecular characterization of Trypanosoma cruzi samples derived from Triatoma vitticeps and Panstrongylus geniculatus of the Atlantic rainforest, southeast Brazil
}

\author{
Maria Augusta Dario ${ }^{1, *}$, Tassiane Emanuelle Servare Andrade ${ }^{1}$, Claudiney Biral dos Santos ${ }^{2}$, Blima Fux ${ }^{1}$, \\ Adeilton Alves Brandão ${ }^{3}$, and Aloísio Falqueto ${ }^{1}$ \\ ${ }^{1}$ Unidade de Medicina Tropical, Universidade Federal do Espírito Santo (UFES), Av. Marechal Campos, 1468, Vitória, \\ ES, 29043-900 Brazil \\ ${ }^{2}$ Núcleo de Entomologia e Malacologia, Secretaria de estado da Saúde (SESA/ES), Rua Pedro Zangradini, 320, \\ Serra ES, 29164-020 Brazil \\ ${ }^{3}$ Laboratório Interdisciplinar em Pesquisas Médicas, Instituto Oswaldo Cruz/Fiocruz, Av. Brasil, 4365, Rio de Janeiro RJ, \\ 21040-900, Brazil
}

Received 20 May 2018, Accepted 6 November 2018, Published online 26 November 2018

\begin{abstract}
Background: In rural areas of Espírito Santo state, southeast Brazil, triatomine species attracted by light frequently invade residences. The aim of this study was to investigate the Trypanosoma cruzi discrete typing units (DTUs) harbored by these triatomines. Methods: Triatomine's intestinal contents were examined, inoculated in mice, and the positive samples were cultivated. Flagellates obtained from infected mice hemoculture were submitted to DNA extraction using a salting-out method and to TcSC5D gene amplification. The amplified samples were sequenced, and polymorphism was analyzed for DTU identification. Results: Three hundred and ninety-four triatomines were identified: Triatoma vitticeps (90.03\%), Panstrongylus geniculatus (8.89\%), Panstrongylus megistus (0.54\%), Panstrongylus diasi (0.27\%), and Triatoma tibiamaculata (0.27\%). Among the specimens, 251/394 $(67.65 \%)$ presented flagellated forms similar to T. cruzi. After triatomine intestinal content inoculation into mice, 134 mice presented T. cruzi-like trypomastigotes from Tr. vitticeps and P. geniculatus and 89 samples were positive in hemoculture. Sixty-two samples were analyzed for the TcSC5D gene and TcI, TcII, TcIII, and TcIV DTUs were identified. Conclusions: We observed T. cruzi DTU diversity in Tr. vitticeps and P. geniculatus, which showed the predominance of TcII and occurrence of TcI, TcIII and TcIV. Triatomines presented high T. cruzi infection rates. Since little is known regarding the possible mammalian hosts that maintain the $T$. cruzi cycle, further studies are necessary to obtain a better understanding of the parasite transmission cycle in this region.
\end{abstract}

Key words: Trypanosoma cruzi discrete typing units, molecular epidemiology, Triatominae, Atlantic rainforest, Brazil.

Résumé - Caractérisation moléculaire d'échantillons de Trypanosoma cruzi dérivés de Triatoma vitticeps et de Panstrongylus geniculatus de la forêt Atlantique, sud-est du Brésil. Contexte : Dans les zones rurales de l'État d'Espírito Santo, au sud-est du Brésil, des espèces de triatomines attirées par la lumière envahissent fréquemment les résidences. Le but de cette étude était d'étudier les unités discrètes de typage (DTU) de Trypanosoma cruzi hébergées par ces triatomines. Méthodes : Le contenu intestinal des triatomines a été examiné, inoculé à des souris et les échantillons positifs ont été cultivés. Les flagellés obtenus à partir d'hémocultures de souris infectées ont été soumis à une extraction d'ADN en utilisant une méthode de relargage et à une amplification du gène TcSC5D. Les échantillons amplifiés ont été séquencés et le polymorphisme a été analysé pour l'identification du DTU. Résultats : Trois cent quatre-vingt-quatorze triatomines ont été identifiées : Triatoma vitticeps (90.03\%), Panstrongylus geniculatus (8.89 \%), Panstrongylus megistus (0.54\%), Panstrongylus diasi $(0.27 \%)$ et Triatoma tibiamaculata $(0.27 \%)$. Parmi les spécimens, 251/394 (67.65\%) présentaient des formes flagellées similaires à celles de T. cruzi. Après inoculation du contenu intestinal des triatomines à des souris, 134 souris ont présenté des trypomastigotes similaires à $T$. cruzi provenant de $T$ r vitticeps et de $P$. geniculatus et 89 échantillons étaient positifs en hémoculture. Soixante-deux échantillons ont été analysés pour le gène TcSC5D et les DTU TcI, TcII, TcIII et TcIV ont été identifiés. Conclusions : Nous avons observé la diversité des DTU de T. cruzi chez Tr. vitticeps et $P$. geniculatus, qui a montré la prédominance de TcII et la présence de TcI, TcIII et TcIV.

\footnotetext{
*Corresponding author: maria_augustadario@yahoo.com.br
} which permits unrestricted use, distribution, and reproduction in any medium, provided the original work is properly cited. 
Les triatomines présentaient des taux d'infection élevés par T. cruzi. Comme on sait peu de choses sur les éventuels hôtes mammifères qui maintiennent le cycle de $T$. cruzi, des études supplémentaires sont nécessaires pour mieux comprendre le cycle de transmission du parasite dans cette région.

\section{Introduction}

Trypanosoma cruzi is transmitted by blood sucking insects termed triatomines. Triatomines belong to the subfamily Triatominae, of which over 130 species are considered as potential T. cruzi vectors [21, 31]. In Brazil, 52 species and three genera: Triatoma, Panstrongylus, and Rhodnius, are registered as causing parasite transmission. Triatomine distribution is related to the overlap of their habitat with human colonization in areas with natural Brazilian Cerrado and Caatinga biomes, whereas Atlantic rainforest fragment areas generally do not present foci of triatomine domiciliation [20].

According to the Instituto de Pesquisas da Mata Atlântica [27], during the last century, the Espírito Santo state (ES) Atlantic rainforest fragment was devastated by wood exploitation and agricultural activities, with only $8.15 \%$ of the natural vegetal cover still remaining. Seven triatomine species are currently reported to occur in this region: Cavernicola pilosa Barber, 1937, Rhodnius domesticus Neiva \& Pinto, 1923, Panstrongylus diasi Pinto \& Lent, 1946, Panstrongylus geniculatus (Latreille, 1811), Panstrongylus megistus (Burmeister, 1835), Triatoma tibiamaculata (Pinto, 1926), and Triatoma vitticeps (Stal, 1859). Although these species present sylvatic habits $[21,56]$, adults are captured by human dwellers inside residences in rural areas, mostly from the ES state mountainous region [30], and Tr. vitticeps have been found colonizing human dwellings $[57,58]$. In this context, Tr. vitticeps constitutes the main captured species, representing high $T$. cruzi natural infection rates $[17,56,60]$.

Serological inquiry in ES state showed a low prevalence $(0.019 \%)$ of Chagas disease (CD) [4, 61], consistent with the ineffectiveness of $T r$. vitticeps to act as a vector through the contaminative route, as adult specimens eliminate their excreta late after their blood meal [57]. Nevertheless, as adult specimens are constantly invading residences, the potential contact with humans includes the risk of parasite transmission by other routes, such as oral transmission. No studies have yet been performed regarding the $T$. cruzi population circulating in triatomine species from ES state, reinforcing the idea that little information is available related to the $T$. cruzi populations in non-endemic areas [64]. Accordingly, the aim of this study was to investigate the $T$. cruzi populations that are present in the triatomine species that invaded residences in rural areas of ES state, which will provide a better understanding of the transmission dynamics of the parasite in the area.

\section{Materials and methods}

\section{Study area}

ES state is located along the southeastern coast of Brazil, encompassing 78 municipalities in a $46.095 \mathrm{~km}^{2}$ area. The municipalities are grouped into four macro regions (Metropolitana, Norte, Central, and South) and ten micro regions (Metropolitana, Central Serrana, Sudoeste Serrana, Litoral Sul, Central Sul, Caparaó, Rio Doce, Centro-Oeste, Nordeste, and Noroeste). The state covers the Atlantic rainforest central corridor, which comprises one of the main dense forest areas inside this biome [30].

\section{Triatomine capture}

ES health agents were trained and instructed to visit rural area residents, teaching them to recognize, capture and preserve the triatomines that invaded their residences, as well as to handle the insects in an approved manner to avoid accidents. Upon capture of a triatomine by an individual in their residence, the insect was taken to a health center nearby or the municipality health agents were contacted to retrieve the triatomines from the residence.

The triatomine species from different localities within ES state collected by residents were delivered by municipality health agents to Núcleo de Entomologia e Malacologia from Secretaria de Estado da Saúde do Espírito Santo (NEMES SESA/ES), located at Departamento de Patologia, Centro Ciências da Saúde, Universidade Federal do Espírito Santo (CCS/UFES), between June 2010 and May 2012. The collection of all the triatomines received was catalogued.

\section{Triatomine identification, examination, and intestinal content inoculation in mice}

Triatomine identification was performed according to Lent and Wygodzinsky [31]. The insect digestive tract was dissected using forceps and scissors. The intestinal contents were diluted in saline solution $(0.85 \%)$ and examined using an optical microscope to examine flagellate forms similar to T. cruzi. Upon positive results, the intestinal content was inoculated into Swiss albino mice by the intraperitoneal route. To confirm parasitemia by $T$. cruzi, the mice were examined every 15 days to observe the presence of trypomastigote bloodstream forms. The animals were examined up to the 60th day. In case of positivity in blood or negativity after the 60-day period, the animals were sacrificed using methods recommended by the Universidade Federal do Espírito Santo Animal Ethics Committee (pentobarbital sodium $40 \mathrm{mg} / \mathrm{kg}$; intraperitoneal route).

\section{Hemoculture examination}

Blood from positive mice was collected by cardiac puncture under anesthesia (acepromazine (2\%) in 9:1 ketamine hydrochloride (10\%)) for subsequent hemoculture in MacNeal, Novy, and Nicole (NNN) medium with Brain Heart Infusion (BHI) overlay, and incubated at $28{ }^{\circ} \mathrm{C}$. The hemocultures were examined under an optical microscope every 15 days until the 60th day. Subsequently, if the hemocultures did not present 
T. cruzi epimastigote forms, they were discarded. Positive hemocultures were washed with $1 \mathrm{~mL}$ of phosphate buffer solution ( $\mathrm{pH} \mathrm{7.2)} \mathrm{and} \mathrm{centrifuged} \mathrm{at} 448 \times g$ for $10 \mathrm{~min}$. The supernatant was discarded, and the pellet was stored at $-20{ }^{\circ} \mathrm{C}$ until DNA extraction.

\section{Trypanosoma cruzi molecular characterization}

Trypanosoma cruzi DNA extraction was performed using a salting out method [2]. For T. cruzi genotyping, the DNA was submitted to polymerase chain reaction (PCR) for the TcSC5D marker using the following primers: TcSC5Dfwd $5^{\prime}$-GGACGTGGCGTTTGATTTAT-3' and TcSC5D-rev $5^{\prime}$-TCCCATCTTCTTCGTTGACT-3' [12], as previously described. In all PCR reactions, we used positive controls and water as a negative control, to validate the reaction.

The 832-bp fragment obtained was purified using a NucleoSpin Extract II purification kit (Macherey-Nagel, Düren, Germany) and then the products were sequenced for the determination of $T$. cruzi genotypes using a BigDye terminator v3.1 cycle sequencing kit (Applied Biosystems, Foster City, CA, USA) on an ABI 3730 DNA sequencer available at the PDTIS/FIOCRUZ sequencing facility. The sequences were edited and corrected using BioEdit software and compared with T. cruzi nucleotide sequences deposited in GenBank using the Basic Local Alignment Search Tool (BLAST) algorithm. The sequences obtained were aligned with reference strain sequences (TcI: X10 - JN050585, DM28 - JN050567; TcII: Y - JN050587, IVV - JN050569; TcIII: M6241 - JN050573, M5631 - JN050572; TcIV: CanIII - JN050566, 91122102R JN050564; TcV: LL014 - JN050570, Sc43 - JN050578; and TcVI: ClBrener - XM797152, Tula - JN050584) and the polymorphisms associated with each genotype were noted, according to those described in Cosentino and Agüero [12], using MEGA5 software [66]. The sequences obtained were deposited in GenBank with accession numbers KY056665-KY056726.

\section{Ethics statement}

This study was approved by the Ethical Animal Use Committee of the Federal University of Espírito Santo (CEUA/UFES), protocol number: 016/2010.

\section{Results \\ Triatomine capture rates and natural T. cruzi infection}

In our study, 394 triatomine specimens were captured in 25 ES municipalities between June 2010 and May 2012, of which 371 were adult specimens and 23 were nymphs. Most were captured in domestic environments, mainly in bedrooms. The adult specimens were identified as: Triatoma vitticeps (334; 90.03\%), Panstrongylus geniculatus (33; 8.89\%), Panstrongylus megistus (2; 0.54\%), Panstrongylus diasi (1;0.27\%), and Triatoma tibiamaculata $(1 ; 0.27 \%)$. All the captured nymphs were from $T r$ vitticeps species. Among the 394 captured triatomines, $251(67.65 \%)$ presented flagellated forms similar
Table 1. Triatomine species and Trypanosoma cruzi infection rates.

\begin{tabular}{lc}
\hline Triatomine species & Specimens infected \\
\hline Triatoma vitticeps & $241(96.02 \%)$ \\
Panstrongylus geniculatus & $9(3.59 \%)$ \\
Panstrongylus megistus & $1(0.39 \%)$ \\
Total & $251(100 \%)$ \\
\hline
\end{tabular}

Table 2. Trypanosoma cruzi DTU identification by triatomine species.

\begin{tabular}{lcccc}
\hline Triatomine species & \multicolumn{4}{c}{ Trypanosoma cruzi DTU } \\
\cline { 2 - 5 } & TcI & TcII & TcIII & TcIV \\
\hline Triatoma vitticeps & 2 & 48 & 3 & 5 \\
Panstrongylus geniculatus & - & 2 & 2 & - \\
Total & 2 & 50 & 5 & 5 \\
\hline
\end{tabular}

to $T$. cruzi (Table 1). None of the 23 nymphs presented such flagellated forms.

\section{Hemoculture and $T$. cruzi genotyping}

Following inoculation into mice of 251 triatomine intestinal contents, 134 mice presented with T. cruzi trypomastigote forms: 127 were from the intestinal contents of $T r$ vitticeps and seven from $P$. geniculatus. Of the 134 hemocultures, 89 presented with $T$. cruzi epimastigote forms, of which 85 samples belonged to Tr. vitticeps and four belonged to $P$. geniculatus.

DNA extraction was performed for 89 cultures in which the presence of $T$. cruzi was evident by microscopy, and PCR amplification products for the TcSC5D gene were obtained for 62 samples. These were genotyped as representing four T. cruzi DTUs circulating in Tr. vitticeps (58 samples) and P. geniculatus (four samples). Of these, 50 samples $(80.65 \%)$ were genotyped as DTU TcII, five $(8.06 \%)$ as TcIII, five $(8.06 \%)$ as TcIV, and two $(3.22 \%)$ as TcI (Tables 2 and 3$)$. This result indicates that in ES state, triatomines demonstrate high diversity of $T$. cruzi DTUs circulating in the sylvatic environment (Fig. 1).

\section{Discussion}

Although only three cases of autochthonous CD have been reported in ES state since 2007, according to the Espírito Santo State Health Department (SESA/ES), triatomines frequently invade residences in rural areas of ES state resulting in the dwelling inhabitants being in contact with this parasite. However, only studies addressing $T$. cruzi infection in triatomines have been mostly reported to date. In contrast, the current report comprises a recent study demonstrating that together with the high rates of $T$. cruzi infection, triatomines represent a source of considerable $T$. cruzi genotype diversity circulating in a given biome.

In this study, we identified five different triatomine species that occur in ES state: Tr. vitticeps, $P$. geniculatus, $P$. megistus, $P$. diasi, and Tr. tibiamaculata, representing the same species 
Table 3. Alignment sequences from Trypanosoma cruzi TcSC5D isolated from Triatoma vitticeps and Panstrongylus geniculatus.

\begin{tabular}{|c|c|c|c|c|c|c|c|c|}
\hline \multirow[b]{2}{*}{ T. cruzi strain/sample } & \multicolumn{8}{|c|}{ Nucleotide position } \\
\hline & 92 & 131 & 290 & 356 & 383 & 449 & 611 & 620 \\
\hline Dm28c (TcI) & $\mathrm{A}$ & $\mathrm{T}$ & $\mathrm{C}$ & $\mathrm{T}$ & $\mathrm{T}$ & $\mathrm{T}$ & $\mathrm{T}$ & $\mathrm{C}$ \\
\hline $\mathrm{X} 10(\mathrm{TcI})$ & . & $\mathrm{G}$ & . & . & . & . & . & . \\
\hline 67 & . & $\mathrm{G}$ & . & . & . & . & . & . \\
\hline 115 & . & . & . & . & . & . & . & . \\
\hline $\mathrm{Y}(\mathrm{TcII})$ & $\mathrm{T}$ & $\mathrm{C}$ & $\mathrm{T}$ & A & $\mathrm{C}$ & . & $\mathrm{G}$ & A \\
\hline IVV (TcII) & $\mathrm{T}$ & $\mathrm{C}$ & $\mathrm{T}$ & $\mathrm{A}$ & $\mathrm{C}$ & . & $\mathrm{G}$ & $\mathrm{A}$ \\
\hline 19 & $\mathrm{~T}$ & $\mathrm{C}$ & $\mathrm{T}$ & A & $\mathrm{C}$ & . & $\mathrm{G}$ & $\mathrm{A}$ \\
\hline 030 & $\mathrm{~T}$ & $\mathrm{C}$ & $\mathrm{T}$ & A & $\mathrm{C}$ & . & $\mathrm{G}$ & $\mathrm{A}$ \\
\hline 075 & $\mathrm{~T}$ & $\mathrm{C}$ & $\mathrm{T}$ & $\mathrm{A}$ & $\mathrm{C}$ & . & $\mathrm{G}$ & $\mathrm{A}$ \\
\hline 160 & $\mathrm{~T}$ & $\mathrm{C}$ & $\mathrm{T}$ & A & $\mathrm{C}$ & . & $\mathrm{G}$ & A \\
\hline 235 & $\mathrm{~T}$ & $\mathrm{C}$ & $\mathrm{T}$ & A & $\mathrm{C}$ & . & $\mathrm{G}$ & A \\
\hline 134 & $\mathrm{~T}$ & $\mathrm{C}$ & $\mathrm{T}$ & A & $\mathrm{C}$ & . & $\mathrm{G}$ & A \\
\hline 001 & $\mathrm{~T}$ & $\mathrm{C}$ & $\mathrm{T}$ & A & $\mathrm{C}$ & . & $\mathrm{G}$ & A \\
\hline 21 & $\mathrm{~T}$ & $\mathrm{C}$ & $\mathrm{T}$ & A & $\mathrm{C}$ & . & $\mathrm{G}$ & $\mathrm{A}$ \\
\hline 031 & $\mathrm{~T}$ & $\mathrm{C}$ & $\mathrm{T}$ & A & $\mathrm{C}$ & . & $\mathrm{G}$ & A \\
\hline 055 & $\mathrm{~T}$ & $\mathrm{C}$ & $\mathrm{T}$ & A & $\mathrm{C}$ & . & $\mathrm{G}$ & A \\
\hline 083 & $\mathrm{~T}$ & $\mathrm{C}$ & $\mathrm{T}$ & A & $\mathrm{C}$ & . & $\mathrm{G}$ & A \\
\hline 165 & $\mathrm{~T}$ & $\mathrm{C}$ & $\mathrm{T}$ & A & $\mathrm{C}$ & . & $\mathrm{G}$ & A \\
\hline 214 & $\mathrm{~T}$ & $\mathrm{C}$ & $\mathrm{T}$ & $\mathrm{A}$ & $\mathrm{C}$ & . & $\mathrm{G}$ & $\mathrm{A}$ \\
\hline 241 & $\mathrm{~T}$ & $\mathrm{C}$ & $\mathrm{T}$ & A & $\mathrm{C}$ & . & $\mathrm{G}$ & A \\
\hline 021 & $\mathrm{~T}$ & $\mathrm{C}$ & $\mathrm{T}$ & A & $\mathrm{C}$ & . & $\mathrm{G}$ & A \\
\hline 032 & $\mathrm{~T}$ & $\mathrm{C}$ & $\mathrm{T}$ & A & $\mathrm{C}$ & . & $\mathrm{G}$ & A \\
\hline 086 & $\mathrm{~T}$ & $\mathrm{C}$ & $\mathrm{T}$ & A & $\mathrm{C}$ & . & $\mathrm{G}$ & A \\
\hline 138 & $\mathrm{~T}$ & $\mathrm{C}$ & $\mathrm{T}$ & A & $\mathrm{C}$ & . & $\mathrm{G}$ & A \\
\hline 168 & $\mathrm{~T}$ & $\mathrm{C}$ & $\mathrm{T}$ & A & $\mathrm{C}$ & . & $\mathrm{G}$ & $\mathrm{A}$ \\
\hline 003 & $\mathrm{~T}$ & $\mathrm{C}$ & $\mathrm{T}$ & A & $\mathrm{C}$ & . & $\mathrm{G}$ & A \\
\hline 23 & $\mathrm{~T}$ & $\mathrm{C}$ & $\mathrm{T}$ & A & $\mathrm{C}$ & . & $\mathrm{G}$ & A \\
\hline 034 & $\mathrm{~T}$ & $\mathrm{C}$ & $\mathrm{T}$ & A & $\mathrm{C}$ &. & $\mathrm{G}$ & A \\
\hline 109 & $\mathrm{~T}$ & $\mathrm{C}$ & $\mathrm{T}$ & A & $\mathrm{C}$ & . & $\mathrm{G}$ & A \\
\hline 196 & $\mathrm{~T}$ & $\mathrm{C}$ & $\mathrm{T}$ & A & $\mathrm{C}$ & . & $\mathrm{G}$ & A \\
\hline 217 & $\mathrm{~T}$ & $\mathrm{C}$ & $\mathrm{T}$ & A & $\mathrm{C}$ & . & $\mathrm{G}$ & $\mathrm{A}$ \\
\hline 209 & $\mathrm{~T}$ & $\mathrm{C}$ & $\mathrm{T}$ & A & $\mathrm{C}$ & . & $\mathrm{G}$ & $\mathrm{A}$ \\
\hline 023 & $\mathrm{~T}$ & $\mathrm{C}$ & $\mathrm{T}$ & $\mathrm{A}$ & $\mathrm{C}$ & . & $\mathrm{G}$ & $\mathrm{A}$ \\
\hline 041 & $\mathrm{~T}$ & $\mathrm{C}$ & $\mathrm{T}$ & A & $\mathrm{C}$ & . & $\mathrm{G}$ & A \\
\hline 113 & $\mathrm{~T}$ & $\mathrm{C}$ & $\mathrm{T}$ & A & $\mathrm{C}$ & . & $\mathrm{G}$ & A \\
\hline 152 & $\mathrm{~T}$ & $\mathrm{C}$ & $\mathrm{T}$ & A & $\mathrm{C}$ & . & $\mathrm{G}$ & A \\
\hline 201 & $\mathrm{~T}$ & $\mathrm{C}$ & $\mathrm{T}$ & A & $\mathrm{C}$ & . & $\mathrm{G}$ & A \\
\hline 010 & $\mathrm{~T}$ & $\mathrm{C}$ & $\mathrm{T}$ & A & $\mathrm{C}$ & . & $\mathrm{G}$ & A \\
\hline 024 & $\mathrm{~T}$ & $\mathrm{C}$ & $\mathrm{T}$ & A & $\mathrm{C}$ & . & $\mathrm{G}$ & A \\
\hline 045 & $\mathrm{~T}$ & $\mathrm{C}$ & $\mathrm{T}$ & A & $\mathrm{C}$ & . & $\mathrm{G}$ & A \\
\hline 153 & $\mathrm{~T}$ & $\mathrm{C}$ & $\mathrm{T}$ & A & $\mathrm{C}$ & . & $\mathrm{G}$ & A \\
\hline 203 & $\mathrm{~T}$ & $\mathrm{C}$ & $\mathrm{T}$ & A & $\mathrm{C}$ & . & $\mathrm{G}$ & A \\
\hline 221 & $\mathrm{~T}$ & $\mathrm{C}$ & $\mathrm{T}$ & A & $\mathrm{C}$ & . & $\mathrm{G}$ & $\mathrm{A}$ \\
\hline 11 & $\mathrm{~T}$ & $\mathrm{C}$ & $\mathrm{T}$ & A & $\mathrm{C}$ & . & $\mathrm{G}$ & $\mathrm{A}$ \\
\hline 025 & $\mathrm{~T}$ & $\mathrm{C}$ & $\mathrm{T}$ & $\mathrm{A}$ & $\mathrm{C}$ & . & G & $\mathrm{A}$ \\
\hline $127-\mathrm{E}$ & $\mathrm{T}$ & $\mathrm{C}$ & $\mathrm{T}$ & A & $\mathrm{C}$ & . & G & A \\
\hline 156 & $\mathrm{~T}$ & $\mathrm{C}$ & $\mathrm{T}$ & $\mathrm{A}$ & $\mathrm{C}$ & . & $\mathrm{G}$ & A \\
\hline 016 & $\mathrm{~T}$ & $\mathrm{C}$ & $\mathrm{T}$ & $\mathrm{A}$ & $\mathrm{C}$ & . & G & $\mathrm{A}$ \\
\hline 29 & $\mathrm{~T}$ & $\mathrm{C}$ & $\mathrm{T}$ & A & $\mathrm{C}$ & . & G & $\mathrm{A}$ \\
\hline 052 & $\mathrm{~T}$ & $\mathrm{C}$ & $\mathrm{T}$ & $\mathrm{A}$ & $\mathrm{C}$ & . & $\mathrm{G}$ & $\mathrm{A}$ \\
\hline 073 & $\mathrm{~T}$ & $\mathrm{C}$ & $\mathrm{T}$ & $\mathrm{A}$ & $\mathrm{C}$ & . & $\mathrm{G}$ & A \\
\hline 129 & $\mathrm{~T}$ & $\mathrm{C}$ & $\mathrm{T}$ & $\mathrm{A}$ & $\mathrm{C}$ & . & $\mathrm{G}$ & A \\
\hline 132 & $\mathrm{~T}$ & $\mathrm{C}$ & $\mathrm{T}$ & $\mathrm{A}$ & $\mathrm{C}$ & . & $\mathrm{G}$ & A \\
\hline 159 & $\mathrm{~T}$ & $\mathrm{C}$ & $\mathrm{T}$ & A & $\mathrm{C}$ & . & $\mathrm{G}$ & $\mathrm{A}$ \\
\hline 231 & $\mathrm{~T}$ & $\mathrm{C}$ & $\mathrm{T}$ & $\mathrm{A}$ & $\mathrm{C}$ & . & $\mathrm{G}$ & $\mathrm{A}$ \\
\hline 205 & $\mathrm{~T}$ & $\mathrm{C}$ & $\mathrm{T}$ & $\mathrm{A}$ & $\mathrm{C}$ & . & $\mathrm{G}$ & $\mathrm{A}$ \\
\hline M6241 (TcIII) & $\mathrm{G}$ & . & . & $\mathrm{G}$ & . & $\mathrm{G}$ & $\mathrm{C}$ & . \\
\hline M5631 (TcIII) & $\mathrm{G}$ & . & & A & . & $\mathrm{G}$ & $\mathrm{C}$ & \\
\hline
\end{tabular}

Table 3. (Continued)

\begin{tabular}{lcccccccc}
\hline & \multicolumn{10}{c}{ Nucleotide position } \\
\cline { 2 - 8 } T. cruzi strain/sample & 92 & 131 & 290 & 356 & 383 & 449 & 611 & 620 \\
\hline 143 & $\mathrm{G}$ &. &. & $\mathrm{G}$ &. & $\mathrm{G}$ & $\mathrm{C}$ &. \\
054 & $\mathrm{G}$ &. &. & $\mathrm{G}$ &. & $\mathrm{G}$ & $\mathrm{C}$ &. \\
049 & $\mathrm{G}$ &. &. & $\mathrm{A}$ &. & $\mathrm{G}$ & $\mathrm{C}$ &. \\
229 & $\mathrm{G}$ &. &. & $\mathrm{A}$ &. & $\mathrm{G}$ & $\mathrm{C}$ &. \\
065 & $\mathrm{G}$ &. &. & $\mathrm{G}$ &. & $\mathrm{G}$ & $\mathrm{C}$ &. \\
210 & $\mathrm{G}$ &. &. & $\mathrm{A}$ &. & $\mathrm{G}$ & $\mathrm{C}$ &. \\
CanIII (TcIV) & $\mathrm{T}$ &. & $\mathrm{A}$ & $\mathrm{A}$ &. &. & $\mathrm{A}$ & $\mathrm{A}$ \\
921221 (TcIV) & $\mathrm{T}$ &. & $\mathrm{A}$ & $\mathrm{A}$ &. &. & $\mathrm{A}$ & $\mathrm{A}$ \\
066 & $\mathrm{~T}$ &. & $\mathrm{~A}$ & $\mathrm{~A}$ &. &. & $\mathrm{~A}$ & $\mathrm{~A}$ \\
064 & $\mathrm{~T}$ &. & $\mathrm{~A}$ & $\mathrm{~A}$ &. &. & $\mathrm{~A}$ & $\mathrm{~A}$ \\
215 & $\mathrm{~T}$ &. & $\mathrm{~A}$ & $\mathrm{~A}$ &. &. & $\mathrm{~A}$ & $\mathrm{~A}$ \\
062 & $\mathrm{~T}$ &. & $\mathrm{~A}$ & $\mathrm{~A}$ &. &. & $\mathrm{~A}$ & $\mathrm{~A}$ \\
LL014 (TcV) & $\mathrm{K}$ & $\mathrm{Y}$ & $\mathrm{Y}$ & $\mathrm{R}$ & $\mathrm{Y}$ & $\mathrm{K}$ & $\mathrm{S}$ & $\mathrm{M}$ \\
Sc43 (TcV) & $\mathrm{K}$ & $\mathrm{Y}$ & $\mathrm{Y}$ & $\mathrm{A}$ & $\mathrm{Y}$ & $\mathrm{K}$ & $\mathrm{S}$ & $\mathrm{M}$ \\
CL Brener (TcVI) & $\mathrm{T}$ & $\mathrm{C}$ & $\mathrm{T}$ & $\mathrm{A}$ & $\mathrm{C}$ &. & $\mathrm{G}$ & $\mathrm{A}$ \\
Tula (TcVI) & $\mathrm{K}$ & $\mathrm{C}$ & $\mathrm{Y}$ & $\mathrm{R}$ & $\mathrm{Y}$ & $\mathrm{K}$ & $\mathrm{S}$ & $\mathrm{M}$ \\
T. c. marinkellei & $\mathrm{T}$ & $\mathrm{C}$ & $\mathrm{T}$ & $\mathrm{A}$ & $\mathrm{T}$ & $\mathrm{A}$ & $\mathrm{A}$ & $\mathrm{A}$ \\
\hline
\end{tabular}

The dots represent the same base position. Trypanosoma cruzi marinkellei (KC881179) was used as the outgroup.

that were found by Leite et al. [30] during an earlier study regarding triatomines in ES state. The occurrence of C. pilosa and $R$. domesticus species has been described previously $[21,25]$, but these species were not identified in the current study. Although Tr. vitticeps is considered a sylvatic species, it is a secondary vector of $\mathrm{CD}$ transmission by the vectorial contaminative route, and has been found frequently in the intradomiciliar environment. This triatomine species exhibits a high T. cruzi infection rate, which has previously been reported in ES as well as in Rio de Janeiro and Minas Gerais states $[22,55,58,59]$. In the present study, among the $67.65 \%$ of triatomines infected with T. cruzi, $64.96 \%$ were from Tr. vitticeps. This high $T$. cruzi infection rate demonstrates a relationship between this triatomine and sylvatic mammals, indicating the capacity of this species to maintain the sylvatic cycle in ES state [57, 58].

Panstrongylus geniculatus and P. megistus were also found to be infected with $T$. cruzi, although with a $T$. cruzi infection rate lower than that of $T r$. vitticeps. Panstrongylus geniculatus is widely distributed in Latin America [29]. This species is correlated with the enzootic cycle and the transmission of CD in Venezuela and Colombia [9, 11, 18, 23]. In Brazil, the species is found in Bahia and in the Amazon region $[19,51,54,67,68]$. Notably, natural T. cruzi infection by $P$. geniculatus has previously been identified only in the Amazon region [51]; the current finding of 33 P. geniculatus specimens from ES state is the first report in the Atlantic rainforest region. Panstrongylus megistus is one of the most important triatomine species domiciliated in Cerrado and Caatinga biomes and can be found from northeast to south Brazil as well as in Bolivia, Paraguay, Uruguay, and Argentina [47, 63]. A study performed by Paula et al. [48] in Minas Gerais state demonstrated that $P$. megistus exhibited a $T$. cruzi infection rate of $8.3 \%$ and that from among a total of 147 specimens identified in Brasilia Federal District, only three (1.45\%) presented 

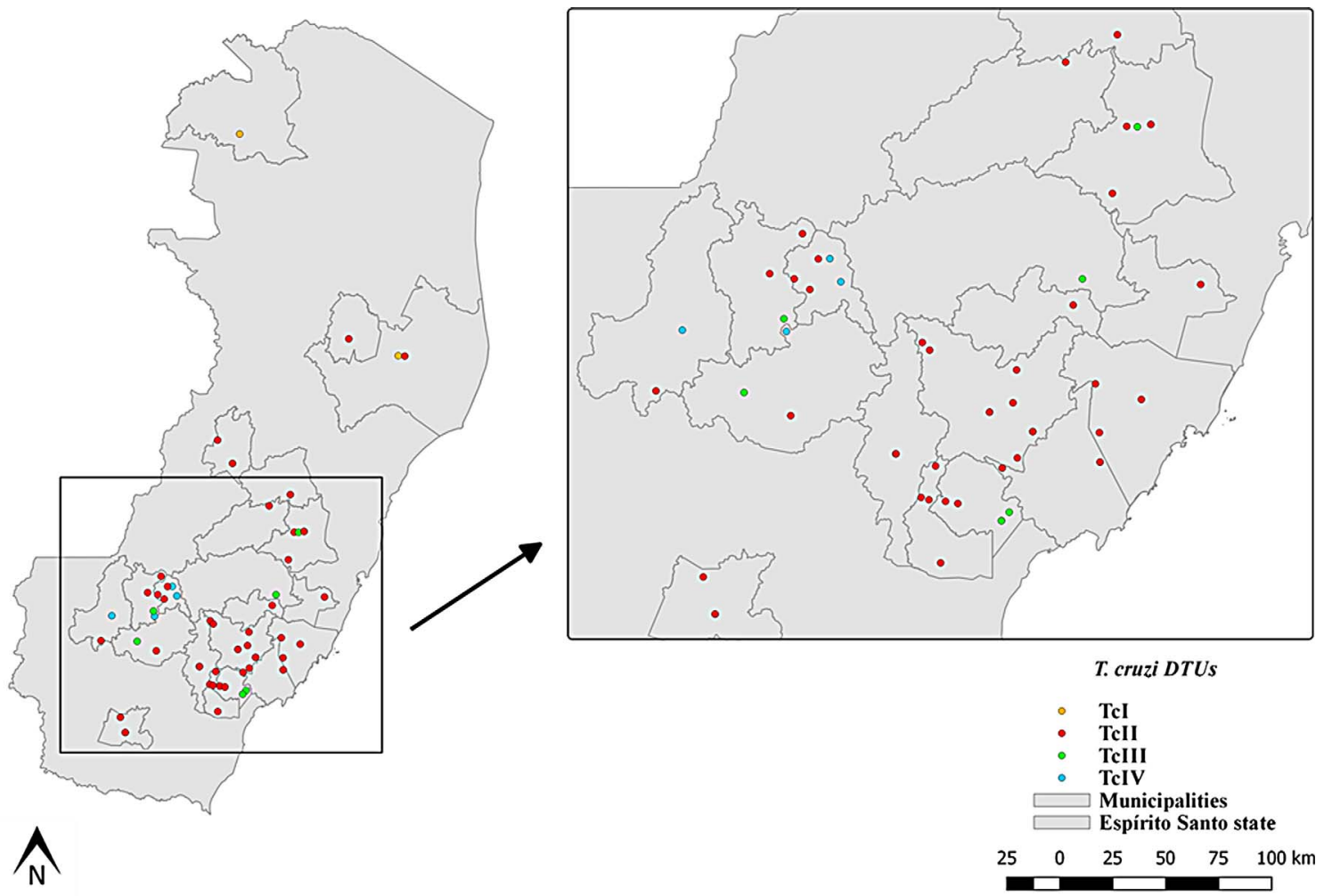

Figure 1. Trypanosoma cruzi DTU distribution in Espírito Santo state. DTUs are coded by color: orange, DTU TcI; red, DTU TcII; green, DTU TcIII; blue, DTU TcIV.

flagellate forms [36]. These results reinforce the low T. cruzi infection rate exhibited by $P$. megistus, which can be justified by its correlation with chicken houses in the peridomicile [5, 48, 69]. However, although P. megistus has been shown to represents an effective $\mathrm{CD}$ vector and to be present in domiciles in Brazilian Cerrado and Caatinga biomes, in the Atlantic rainforest it is predominantly sylvatic, as was also observed by Barbosa et al. [3] in Santa Catarina state.

Trypanosoma cruzi is a genetically diverse parasite: six T. cruzi populations are recognized, denoted as TcI to TcVI, as well as a seventh DTU termed TcBat [38, 71, 72]. Notably, in Brazil, the existence of a heterogeneous T. cruzi population supporting the occurrence of the six T. cruzi DTUs has been reported $[6,14,43,65]$. In the present study, the T. cruzi genotypes circulating in triatomines from the Atlantic rainforest were found to be genetically heterogeneous, with the predominance of DTU TcII and DTUs TcI, TcIII, and TcIV were also presented. This DTU diversity was observed in Guarapari municipality, ES state, in which the DTUs TcI, TcII, TcIII and TcIV were identified infecting triatomines $[15,16]$.

DTU TcII is found in the southern cone of South America [72], although its occurrence has been reported in the Amazon region, Colombia, Mexico, and the United States [26, 32, 37, 50]. According to Miles et al. [44], TcII is rarely found in the sylvatic cycle; however, in the Atlantic rainforest, it has been reported in primates and has been isolated from the armadillo (Euphractus sexcinctus) as well [33, 34, 70]. Notably, whereas all $C D$ vectors in ES state are in sylvatic areas, the occurrence of DTU TcII was predominant in this environment. As T. cruzi is known to circulate in more than 100 mammal species [28], this genotype likely already existed in this environment prior to triatomine domiciliation. DTU TcI has a wide distribution on the American continent and is responsible for CD cases in Central and Northern South America. It is correlated to the arboreal transmission cycle in nature and opossums from Didelphis sp. comprise the main reservoir [9, 72, 42, 7, $68,24]$. Although TcI is very commonly found in nature, in ES state only two samples were identified in Tr. vitticeps, which contrasts with a previous report of infection of this triatomine by DTU TcI at a high percentage [53].

In turn, DTU TcIII can be found in different regions in Brazil; this genotype has been found to be responsible for cases of CD in North, Northeast, Southeast, and South Brazilian regions [1, 35, 40, 45]. It is correlated to the terrestrial transmission cycle, with its main vector being $P$. geniculatus species [39]. In the present study, we described the occurrence of DTU TcIII in $P$. geniculatus and in Tr. vitticeps. In comparison, according to Cardinal et al. [8] and Martins et al. [41], TcIII was described as infecting triatomines from $T$. rubrovaria and $T$. infestans, respectively. The demonstration of the infection of additional triatomine species by this genotype reinforces the notion that the correlations between single species and genotypes remain poorly understood. Finally, DTU TcIV is encountered from the southern United States to northern South America and, together with TcI, is responsible for CD cases in the Amazon region [10, 24, 46, 50, 52]. The reporting of TcIV in Tr. vitticeps in ES state shows that its distribution is more extensive than has been reported. This finding also reinforces the Amazon enclave theory proposed by Costa [13], which states that a thousand years ago, the Atlantic rainforest 
and the Amazon were connected. In support of this theory, Pinto et al. [49] and Silva et al. [62] reported the appearance of distinct species of sandflies and Anopheles mosquitoes from the Amazon in the ES Atlantic rainforest. Our report of T. cruzi populations that occurred both in the Amazon and in the Atlantic rainforest thus serves to further support this theory.

This study is the first report of T. cruzi DTUs in different municipalities from ES state, as prior studies were limited to investigating only $T$. cruzi infection rates in triatomines. Our results demonstrate that $T$. cruzi DTU distribution is much broader than has previously been reported; for example, TcII, which was associated with the domestic transmission cycle, was found to be widely distributed in nature. Furthermore, it was observed that the small Atlantic rainforest fragment studied herein presented marked diversity of circulating DTUs and that one triatomine species, Tr. vitticeps, hosted four different T. cruzi genotypes. For future studies, it is necessary to understand the ecological scenario that maintains DTU diversity in this biome.

\section{Conflict of interest}

The authors declare that they have no competing interests.

Acknowledgements. We would like to thank the Núcleo de Entomologia e Malacologia da Secretária de Estado da Saúde (Nemes-SESA/ES), which provided the triatomines for the study, the Instituto de Defesa Agropecuária e Florestal do Espírito Santo (IDAF), and the biotherium of the Universidade Federal do Espírito Santo (UFES), which provided the mice for the study. We also thank Dr. Gustavo Rocha Leite and Dr. Franklyn Samudio for technical support in the analyses of the results and laboratory procedures, respectively; to Dr. Constança Brito and Dr. Myllena Melo who provided the T. cruzi reference strains for the experimental work; to Dr. Samanta Cristina das Chagas Xavier for helpful with figure design and to the PDTIS/Fiocruz sequencing platform for sequencing the samples. We would also like to thank Dr. Ana Maria Jansen for the consistently helpful comments. This study was funded by Instituto Oswaldo Cruz - IOC/Fiocruz and Universidade Federal do Espírito Santo - UFES. A master's degree grant was provided by the Coordination for the Improvement of Higher Education Personnel (CAPES) to MAD and an undergraduate grant was provided by the Brazilian National Council for Scientific and Technological Development (CNPq) to TESA. The funders had no role in study design, data collection and analysis, decision to publish, or preparation of the manuscript.

\section{References}

1. Abolis NG, de Araujo SM, Toledo MJO, Fernandez MA, Gomes ML. 2011. Trypanosoma cruzi I-III in Southern Brazil causing individual and mixed infections in humans, sylvatic reservoirs and triatomines. Acta Tropica, 120, 167-172.

2. Aljanabi SM, Martinez I. 1997. Universal and rapid saltextraction of high quality genomic DNA for PCR-based techniques. Nucleic Acids Research, 25, 4692-4693.

3. Barbosa SE, Belisário CJ, Souza RCM, Paula AS, Linardi PM, Romanha AJ, Diotaiutti L. 2006. Biogeography of Brazilian populations of Panstrongylus megistus (Hemiptera, Reduviidae, Triatominae) based on molecular marker and paleo vegetational data. Acta Tropica, 99, 144-154.
4. Barros GC, Mayrink W, Salgado AA, Barros RCG, Sessa PA. 1975. Contribuição para o conhecimento da doença de Chagas autóctone no estado do Espírito Santo. Revista do Instituto de Medicina Tropical de São Paulo, 17, 319-329.

5. Belisário CJ, Dias JVL, Diotaiutti L. 2013. Profile of the Trypanosoma cruzi vector infestation in Jaboticatubas, State of Minas Gerais, Brazil. Revista da Sociedade Brasileira de Medicina Tropical, 46(6), 779-782.

6. Brenière SF, Waleckx E, Barnabé C. 2016. Over six thousand Trypanosoma cruzi strains classified into Discrete Typing Units (DTUs): attempt at an inventory. PLoS Neglected Tropical Diseases, 10(8), e0004792.

7. Briones MR, Souto RP, Stolf BS, Zingales B. 1999. The evolution of two Trypanosoma cruzi subgroups inferred from rRNA genes can be correlated with the interchange of American mammalian faunas in the Cenozoic and has implications to pathogenicity and host specificity. Molecular and Biochemical Parasitology, 104, 219-232.

8. Cardinal MV, Lauricella MA, Ceballos LA, Lanati L, Marcet PL, Levin MJ, Kitron U, Gürtler RE, Schijman AG. 2008. Molecular epidemiology of domestic and sylvatic Trypanosoma cruzi infection in rural northwestern Argentina. International Journal of Parasitology, 38, 1533-1543.

9. Carrasco HJ, Torrellas A, García C, Segovia M, Feliciangeli MD. 2005. Risk of Trypanosoma cruzi I (kinetoplastida: trypanosomatidae) transmission by Panstrongylus geniculatus (Hemiptera: Reduviidae) in Caracas (metropolitan district) and neighboring states, Venezuela. International Journal of Parasitology, 35, 1379-1384.

10. Carrasco HJ, Segovia M, Llewellyn MS, Morocoima A, Urdaneta-Morales S, Martínez C, Martínez CE, Garcia C, Rodríguez M, Espinosa R, de Noya BA, Díaz-Bello Z, Herrera L, Fitzpatrick S, Yeo M, Miles MA, Feliciangeli MD. 2012. Geographical distribution of Trypanosoma cruzi genotypes in Venezuela. PLoS Neglected Tropical Diseases, DOI: 10.1371/journal.pntd.0001707.

11. Carrasco HJ, Segovia M, Londoño JC, Ortegoza J, Rodríguez M, Martínez CE. 2014. Panstrongylus geniculatus and four other species of triatomines bug involved in the Trypanosoma cruzi enzootic cycle: high risk factors for Chagas' disease transmission in the metropolitan district of Caracas, Venezuela. Parasites and Vectors, 7, 602.

12. Cosentino RO, Agüero F. 2012. A simple strain-typing assay for Trypanosoma cruzi: Discrimination of major evolutionary lineages from a single amplification product. PLoS Neglected Tropical Diseases, 6(7), e1777.

13. Costa LP. 2003. The historical bridge between the Amazon and the Atlantic forest of Brazil: a study of molecular phylogeography with small mammals. Journal of Biogeography, 30, 7186.

14. Coura JR, Junqueira ACV, Fernandes O, Valente SAS, Miles MA. 2002. Emerging Chagas disease in Amazonian Brazil. Trends in Parasitology, 18, 171-176.

15. Dario MA, Rodrigues MS, Barros JH, Xavier SC, D'Andrea PS, Roque AL, Jansen AM. 2016. Ecological scenario and Trypanosoma cruzi DTU characterization of a fatal acute Chagas disease case transmitted orally (Espírito Santo state, Brazil). Parasites and Vectors, 31(9), 477.

16. Dario MA, Lisboa CV, Costa LM, Moratelli R, Nascimento MP, Costa LP, Leite YLR, Llewellyn MS, Xavier SCDC, Roque ALR, Jansen AM. 2017. High Trypanosoma spp. diversity is maintained by bats and triatomines in Espírito Santo state, Brazil. PLoS One, 12(11), e0188412.

17. Dias JCP, Feitosa VR, Filho ANF, Rodrigues VLC, Alencar AS, Sessa PA. 1989. Fonte alimentar e potencial vetorial de Triatoma vitticeps (Stal, 1859) com relação à doença de 
Chagas humana no estado do Espírito Santo, Brasil. Memórias do Instituto Oswaldo Cruz, 84, 165-173.

18. Escalante ME, Gomez D, Silveira LA, Sánchez G, Venegas J. 2015. Detection of high percentage of Trypanosoma cruzi infection, the etiologic agent of Chagas disease, in wild populations of Colombian Caribbean triatomines. Acta Parasitologica, 60(2), 315-321.

19. Fe NF, Magalhães LK, Fe FA, Arakian SK, Monteiro WM, Barbosa MD. 2009. Occurrences of triatomines in wild and domestic environments in the municipality of Manaus, state of Amazonas. Revista da Sociedade Brasileira de Medicina Tropical, 42, 642-646.

20. Forattini OP. 1980. Biogeografia, origem e distribuição da domiciliação de triatomíneos no Brasil. Revista de Saúde Pública, 14, 265-299.

21. Galvão C, Carcavallo R, Rocha DS, Jurberg J. 2003. A checklist of the current valid species of the subfamily Triatominae Jeannel, 1919 (Hemiptera, Reduviidae) and their geographical distribution, with nomenclatural and taxonomic notes. Zootaxa, 202, 1-36.

22. Gonçalves TC, de Oliveira E, Dias LS, Almeida MD, Nogueira WO, Pires FD. 1998. An investigation on the ecology of Triatoma vitticeps (Stal, 1859) and its possible role in the transmission of Trypanosoma cruzi, in the locality of Triunfo, Santa Maria Madalena municipal district, state of Rio de Janeiro, Brazil. Memórias do Instituto Oswaldo Cruz, 93(6), 711-717.

23. Guhl F, Aguilera G, Pinto N, Vergara D. 2007. Actualización de la distribución geográfica y ecoepidemiología de la fauna de triatominos (Reduviidae: Triatominae) en Colombia. Biomedica, 27, 143-162.

24. Guhl F, Ramírez JD. 2013. Retrospective molecular integrated epidemiology of Chagas disease in Colombia. Infection Genetics and Evolution, 20, 148-154.

25. Gurgel-Gonçalves R, Galvão C, Costa J, Peterson AT. 2012. Geographic distribution of Chagas disease vectors in Brazil based on ecological niche modeling. Journal of Tropical Medicine, 2012, DOI:10.1155/2012/705326.

26. Herrera CP, Licon MH, Nation CS, Jameson SB, Wesson DM. 2015. Genotype diversity of Trypanosoma cruzi in small rodents and Triatoma sanguisuga from a rural area in New Orleans, Louisiana. Parasites and Vectors, 8, 123.

27. Instituto de Pesquisas da Mata Atlântica. 2004. Conservação da Mata Atlântica no Estado do Espírito Santo: Cobertura Florestal, Unidades de Conservação e Fauna Ameaçada (Programa Centros para a Conservação da Biodiversidade Conservação Internacional do Brasil). Vitória: IPMA.

28. Jansen AM, Roque ALR. 2010. Domestic and wild mammalian reservoir, in American trypanosomiasis Chagas Disease - one hundred years of research. Telleria J, Tibayrenc M, Editors. Elsevier: London. p. 249-276.

29. Leite GR, dos Santos CB, Falqueto A. 2007. Insecta, Hemiptera, Reduviidae, Panstrongylus geniculatus: geographic distribution map. Check List, 147-152.

30. Leite GR, dos Santos CB, Falqueto A. 2011. Influence of the landscape on dispersal of sylvatic triatomines to anthropic habitats in the Atlantic Forest. Journal of Biogeography, 38(4), 651-663.

31. Lent H, Wygodzinsky P. 1979. Triatominae. Bulletin of the American Museum of Natural History, 163, 496-497.

32. Lima VdS, Xavier SCdC, Maldonado IFR, Roque ALR, Vicente ACP, Jansen AM. 2014. Expanding the knowledge of the geographic distribution of Trypanosoma cruzi TcII and TcV/TcVI genotypes in the Brazilian Amazon. PLoS One, 9(12), e116137.
33. Lisboa CV, Mangia RH, de Lima NR, Martins A, Dietz J, Baker AJ, Ramon-Miranda CR, Ferreira LF, Fernandes O, Jansen AM. 2004. Distinct patterns of Trypanosoma cruzi infection in Leontopithecus rosalia in distinct Atlantic coastal rainforest fragments in Rio de Janeiro-Brazil. Parasitology, 129, 703-711.

34. Lisboa CV, Mangia RH, Luz SLB, Kluczkovskia A Jr., Ferreira LF, Ribeiro CT, Fernandes O, Jansen AM. 2006. Stable infection of primates with Trypanosoma cruzi I e II. Parasitology, 133, 603-611.

35. Llewellyn MS, Lewis MD, Acosta N, Yeo M, Carrasco HJ, Segovia M, Vargas J, Torrico F, Miles MA, Gaunt MW. 2009. Trypanosoma cruzi IIc: phylogenetic and phylogeographic insights from sequence and microsatellite analysis and potential impact on emergent Chagas' disease. PLoS Neglected Tropical Diseases, 3, e510.

36. Maeda MH, Knox MB, Gurgel-Gonçalves R. 2012. Occurrence of synanthropic triatomines (Hemiptera: Reduviidae) in the Federal District of Brazil. Revista da Sociedade Brasileira de Medicina Tropical, 45(1), 71-76.

37. Mantilla JC, Zafra GA, Macedo AM, González CI. 2010. Mixed infection of Trypanosoma cruzi I and II in a Colombian cardiomyopathic patient. Human Pathology, 41, 610-613.

38. Marcili A, Lima L, Cavazzana M, Junqueira AC, Veludo HH, Da Silva FM, Campaner M, Paiva F, Nunes VL, Teixeira MM. 2009. A new genotype of Trypanosoma cruzi associated with bats evidenced by phylogenetic analyses using SSU rDNA, cytochrome $\mathrm{b}$ and Histone $\mathrm{H} 2 \mathrm{~B}$ genes and genotyping based on ITS1 rDNA. Parasitology, 136, 641-655.

39. Marcili A, Lima L, Valente VC, Valente SA, Batista JS, Junqueira AC, Souza AI, da Rosa JA, Campaner M, Lewis MD, Llewellyn MS, Miles MA, Teixeira MM. 2009. Comparative phylogeography of Trypanosoma cruzi TCIIc: new hosts, association with terrestrial ecotopes, and spatial clustering. Infection Genetics and Evolution, 9(6), 1265-1274.

40. Martins K, Andrade CM, Barbosa-Silva NA, Nascimento GB, Chiari E, Galvão LM, da Câmara AC. 2015. Trypanosoma cruzi III causing the indeterminate form of Chagas disease in a semiarid region of Brazil. International Journal of Infection Diseases, 39, 68-75.

41. Martins LP, Marcili A, Castanho RE, Therezo AL, de Oliveira JC, Suzuki RB, Teixeira MM, da Rosa JA, Sperança MA. 2008. Rural Triatoma rubrovaria from southern Brazil harbors Trypanosoma cruzi of lineage IIc. American Journal of Tropical Medicine and Hygiene, 79, 427-434.

42. Miles MA, Povoa MM, Prata A, Cedillos RA, de Souza AA, Macedo V. 1981. Do radically dissimilar Trypanosoma cruzi strains (zymodemes) cause Venezuelan and Brazilian forms of Chagas' disease? Lancet, 20(1), 1338-1340.

43. Miles MA, Yeo M, Gaunt M. 2003. Genetic diversity of Trypanosoma cruzi and the epidemiology of Chagas disease, in Molecular Mechanisms in the Pathogenesis of Chagas Disease. Kelly JM, Editor. Kluwer Academic/Plenum: New York. p. 1-13.

44. Miles MA, Llewllyn MS, Lewis MD, Yeo M, Baleela R, Fitzpatrick S, Gaunt MW, Mauricio IL. 2009. The molecular epidemiology and phylogeography of Trypanosoma cruzi and parallel research on Leishmania: looking back and to the future. Parasitology, 136, 1509-1528.

45. Monteiro WM, Magalhães LK, Santana-Filho FS, Borborema M, Silveira H, Barbosa MG. 2010. Trypanosoma cruzi TcIII/Z3 genotype as agent of an outbreak of Chagas disease in the Brazilian Western Amazonia. Tropical Medicine and International Health, 15, 1049-1051.

46. Monteiro WM, Magalhaes LKC, de Sá ARN, Gomes ML, Toledo MJO, Borges L, Pires I, Guerra JA, Silveira H, Barbosa Md. 2010. Trypanosoma cruzi IV causing outbreaks of acute 
Chagas disease and infections by different haplotypes in the Western Brazilian Amazonia. PLoS One, 7(7), e41284.

47. Patterson JS, Barbosa SE, Feliciangeli MD. 2009. On the genus Panstrongylus Berg 1879: evolution, ecology and epidemiological significance. Acta Tropica, 110, 187-199.

48. Paula MB, Costa IN, PdeA Freitas, Limongi JE, Pajuaba Neto Ade A, RdeM Pinto, Gonçalves AL, Costa-Cruz JM. 2010. Occurrence of positivity for Trypanosoma cruzi in triatomine from municipalities in Southeastern Brazil, from 2002 to 2004. Revista da Sociedade Brasileira de Medicina Tropical, 43(1), 9-14.

49. Pinto IS, Santos CB, Ferreira AL, Falqueto A. 2010. Richness and diversity of sand flies (Diptera, Psychodidae) in an Atlantic rainforest reserve in southeastern Brazil. Journal of Vector Ecology, 35(2), 325-331.

50. Ramos-Ligonio A, Torres-Montero J, Lopez-Monteon A, Dumonteil E. 2012. Extensive diversity of Trypanosoma cruzi discrete typing units circulating in Triatoma dimidiata from central Veracruz. Mexico. Infection Genetics and Evolution, 12(7), 1341-1343.

51. Ribeiro AR, Mendonça VJ, Alves RT, Martinez I, de Araújo RF, Mello F, da Rosa JA. 2014. Trypanosoma cruzi strains from triatomine collected in Bahia and Rio Grande do Sul. Brazil. Revista de Saúde Pública, 48(2), 295-302.

52. Roellig DM, Savage MY, Fujita AW, Barnabe C, Tibayrenc M, Steurer FJ, Yabsley MJ. 2013. Genetic variation and exchange in Trypanosoma cruzi isolates from the United States. PLoS One, 8(2), e56198.

53. Sangenis LH, Saraiva RM, Georg I, de Castro L, dos Santos Lima V, Al Roque, Xavier SC, Santos LC, Fernandes FA, Sarquis O, Lima MM, Carvalho-Costa FA, Bóia MN. 2015. Autochthonous transmission of Chagas disease in Rio de Janeiro state, Brazil: a clinical and eco-epidemiological study. BMC Infection Diseases, 15, 4.

54. Santana KDES, Bavia ME, Lima AD, Guimarães ICS, Soares ES, Silva MM, Mendonça J, MdeS Martin. 2011. Spatial distribution of triatomines (Reduviidae: Triatominae) in urban areas of the city of Salvador, Bahia, Brazil. Geospatial Health, 5(2), 199-203.

55. Santos AD, Letro RB, Lemos do Bem VA, Azeredo BV, Coelho GL, Diotaiuti L, Machado-de-Assis GF, de Lana M. 2014. Evaluation of the Chagas disease control program in Açucena municipality, Rio Doce valley, state of Minas Gerais, Brazil. Revista da Sociedade Brasileira de Medicina Tropical, 47(2), 186-192.

56. Santos CB, Leite GR, Sessa PA, Ferreira AL, Ferreira GEM, Falqueto A. 2004. Potencial vetorial de Triatoma vitticeps (Stal 1859) (Hemiptera, Reduviidae, Triatominae) na transmissão do Trypanosoma cruzi (Chagas, 1909) (Kinetoplastidae, Trypanosomatidae) no estado do Espírito Santo, Brasil. Revista da Sociedade Brasileira de Medicina Tropical, 37(1), 186.

57. Santos CB, Ferreira AL, Leite GR, Ferreira GE, Rodrigues AA, Falqueto A. 2005. Peridomiciliary colonies of Triatoma vitticeps (Stal, 1859) (Hemiptera, Reduviidae, Triatominae) infected with Trypanosoma cruzi in rural areas of the state of Espírito Santo, Brazil. Memórias do Instituto Oswaldo Cruz, 100(5), 471-473.

58. Santos CB, Leite GR, Ferreira GEM, Ferreira AL. 2006. Infecção natural de Triatoma vitticeps (Stal, 1859) por flagelados semelhantes a Trypanosoma cruzi (Chagas, 1909) no estado do Espírito Santo. Revista da Sociedade Brasileira de Medicina Tropical, 39(1), 89-91.

59. Santos UM, Pinto AFS, Almeida AZ, Zaganelli FL, Carancho PV, Netto AN. 1969. Doença de Chagas no Estado do Espírito
Santo. III - Vetores do tripanosoma. Revista da Sociedade Brasileira de Medicina Tropical, 3, 51-52.

60. Sessa PA, Carias VRD. 1986. Infecção natural de triatomíneos do Espírito Santo for flagelados morfologicamente semelhantes ao Trypanosoma cruzi. Revista da Sociedade Brasileira de Medicina Tropical, 19, 99-100.

61. Sessa PA, Pimentel RR, Ferreira AL, Falqueto A. 2002. Soroprevalência da doença de Chagas em crianças em idade escolar do Estado do Espírito Santo, Brasil, em 1999-2000. Caderno de Saúde Pública, 18, 1765-1769.

62. Silva KS, Pinto IS, Leite GR, Virgens TM, Santos CB, Falqueto A. 2013. Ecology of anopheline mosquitoes (Diptera: Culicidae) in the central Atlantic Forest biodiversity corridor, southeastern Brazil. Journal of Medical Entomology, 50(1), 24-30.

63. Silveira AC. 2011. Entomological survey (1975-1983). Revista da Sociedade Brasileira de Medicina Tropical, 44(2), 26-32.

64. Steindel M, Toma HK, Ishida MI, Murta SMF, Pinto CJC, Grisard EC, Schlemper BR Jr, Ribeiro-Rodrigues R, Romanha AJ. 1995. Biological and isoenzymatic characterization of Trypanosoma cruzi strains isolated from sylvatic reservoirs and vectors from the state of Santa Catarina, Southern Brazil. Acta Tropica, 60, 167-177.

65. Sturm N, Campbell DA. 2010. Alternative lifestyles: the population structure of Trypanosoma cruzi. Acta Tropica, 115, $35-43$.

66. Tamura K, Peterson D, Peterson N, Stecher G, Nei M, Kumar S. 2011. MEGA5: molecular evolutionary genetics analysis using maximum likelihood, evolutionary distance, and maximum parsimony methods. Molecular Biology and Evolution, 28(10), 2731-2739.

67. Valente VC, Valente SAS, Noireau F, Carrasco HJ, Miles MA. 1998. Chagas disease in the Amazon Basin: association of Panstrongylus geniculatus (Hemiptera, Reduviidae) with domestic pigs. Journal of Medical Entomology, 35, 99-103.

68. Valente SADS, Valente VDC, Pinto AYDN, César MDJB, Santos MPD, Miranda COS, Cuervo P, Fernandes O. 2009. Analysis of an acute Chagas disease outbreak in the Brazilian Amazon: human cases, triatomines, reservoir mammals and parasites. Transactions of the Royal Society of Tropical Medicine and Hygiene, 103, 291-297.

69. Villela MM, de Souza JMB, Melo Vde P, Dias JCP. 2009. Avaliação do Programa de Controle da Doença de Chagas em relação à presença de Panstrongylus megistus na região centrooeste do Estado de Minas Gerais, Brasil. Caderno de Saúde Pública, 25(4), 907-917.

70. Yeo M, Acosta N, Llewellyn M, Sanchez H, Adamson S, Miles GA, López E, González N, Patterson JS, Gaunt MW, de Arias AR, Miles MA. 2005. Origins of Chagas disease: Didelphis species are natural hosts of Trypanosoma cruzi I and armadillos hosts of Trypanosoma cruzi II, including hybrids. International Journal of Parasitology, 35, 225-233.

71. Zingales B, Andrade SG, Briones MR, Campbell DA, Chiari E, Fernades O, Guhl F, Lages-Silva E, Macedo AM, Machado CR, Miles MA, Romanha AJ, Sturm NR, Tibayrenc M, Schijman AG. 2009. A new consensus for Trypanosoma cruzi intraspecific nomenclature: second revision meeting recommends TcI to TcVI. Memórias do Instituto Oswaldo Cruz, 104, 1051-1054.

72. Zingales B, Miles MA, Campbell DA, Tibayrenc M, Macedo AM, Teixeira MMG, Schijman AG, Llewellyn MS, Lages-Silva E, Machado CR, Andrade SG, Sturm NR. 2012. The revised Trypanosoma cruzi subspecific nomenclature: rationale, epidemiological relevance and research applications. Infection Genetics and Evolution, 12, 240-253. 
Cite this article as: Dario MA, Andrade TE, dos Santos CB, Fux B, Brandão AA \& Falqueto A. 2018. Molecular characterization of Trypanosoma cruzi samples derived from Triatoma vitticeps and Panstrongylus geniculatus of the Atlantic rainforest, southeast Brazil. Parasite 25, 59.

\section{- PARASTE}

An international open-access, peer-reviewed, online journal publishing high quality papers on all aspects of human and animal parasitology

Reviews, articles and short notes may be submitted. Fields include, but are not limited to: general, medical and veterinary parasitology; morphology, including ultrastructure; parasite systematics, including entomology, acarology, helminthology and protistology, and molecular analyses; molecular biology and biochemistry; immunology of parasitic diseases; host-parasite relationships; ecology and life history of parasites; epidemiology; therapeutics; new diagnostic tools.

All papers in Parasite are published in English. Manuscripts should have a broad interest and must not have been published or submitted elsewhere. No limit is imposed on the length of manuscripts.

Parasite (open-access) continues Parasite (print and online editions, 1994-2012) and Annales de Parasitologie Humaine et Comparée (1923-1993) and is the official journal of the Société Française de Parasitologie. 